\title{
EFEK LAMA WAKTU PENGGUNAAN Smilax $S p$ TERHADAP EDEMI PADA Femur Gallus gallus domesticus
}

\author{
Jean Christi Pellaupessy ${ }^{1}$, Aung Sumbono ${ }^{2.3}$, Jaharudin ${ }^{1}$ \\ ${ }^{1}$ Program Studi Pendidikan Biologi UNIMUDA Sorong \\ ${ }^{2}$ LP3M UNIMUDA Sorong \\ ${ }^{3}$ Program Studi Farmasi UNIMUDA Sorong \\ jeanpellaupessy@gmail.com
}

\begin{abstract}
ABSTRAK
Penelitian ini bertujuan untuk mengetahui efek lama waktu penggunaan Smilax Sp terhadap edemi pada Femur Gallus gallus domesticus $(F g g d)$. Metode penelitian eksperimen. Sampel yang digunakan yakni tumbuhan Smilax Sp dan Fggd, sampel Smilax Sp yang digunakan untuk masing-masing sampel Fggd sebanyak 25 gram, Fggd yang digunakan sebagai sampel berusia 21 hari sebanyak 12. Penelitian dilakukan di Laboratorium Terpadu, UNIMUDA Sorong pada Mei 2019. Instrument yang digunakan yakni observasi dan dokumentasi. Teknik analisis data dalam penelitian ini menggunakan metode analisis komparasi yaitu membandingkan ukuran dan massa Fggd sampel dengan Fggd kontrol, dan akan dideskripsikan secara terperinci. Berdasarkan hasil penelitian maka dapat disimpulkan bahwa lama waktu penggunaan daun Smilax Sp berdampak terhadap proses edemi pada superius femur, inferior femur, sinistram femur musculus, dextro femore, musculus quadriceps, posteriorem femoris dan massa femur dengan proses edemi maksimum terjadi pada waktu 14 jam, dengan persentasi edemi sebesar $114 \%$.
\end{abstract}

Kata Kunci : Smilax Sp, edemi, waktu, femur

\section{ABSTRACT}

This study aims to determine the effect of the length of time using Smilax Sp on edema in Femur Gallus gallus domesticus (Fggd). Experimental research methods. The samples used were Smilax Sp and Fggd plants, Smilax Sp samples used for each Fggd sample were 25 grams, Fggd used as 21 day old samples were 12. The study was conducted at the Integrated Laboratory, UNIMUDA Sorong in May 2019. The instruments used were used namely observation and documentation. The data analysis technique in this study uses a comparative analysis method that compares the size and mass of Fggd samples with control Fggd, and will be described in detail. Based on the results of the study it can be concluded that the length of time using Smilax Sp leaves has an impact on the edema process in the superius femur, inferior femur, sinistram femur musculus, dextro femore, quadriceps musculus, posteriorem femoris and femoral mass with a maximum edema process occurring within 14 hours, with the percentage of edema is $114 \%$.

Keywords: Smilax Sp, edemic, time, femur

\section{PENDAHULUAN}

Edemi merupakan pembengkakan yang disebabkan karena akumulasi cairan untuk melepaskan cairan dari pembuluh darah kecil (kapiler) atau ruang interstisial ke jaringan di sekitarnya (1). Edemi paling sering terjadi di kaki, pergelangan kaki dan bahkan bisa mempengaruhi bagian tubuh lainnya (1) yang merupakan efek samping penggunaan banyak obat. Penyebab umum edemi yakni obat-obatan, asupan garam yang berlebihan, menopause dan kehamilan, malnutrisi, luka bakar, panas (2). Edemi juga dapat ditimbulkan dari penyakit ginjal, gagal jantung, insufisiensi vena, penyakit paru-paru kronis, hati, diabetes, alergi, penyakit ginjal (3).

Efek lain juga dapat muncul akibat -

dari penggunaan obat dalam dosis yang besar atau dalam jangka waktu yang lama. Pemberian obat dengan dosis yang berlebihan akan menyebabkan over dosis dan dapat meningkatkan risiko terjadinya ketoksikan, jika dosis yang diberikan kurang dari standarnya pengobatan menjadi tidak optimal dan kurang tercapainya efek yang diharapkan (4). Tidak hanya obat sintesis, bahan alam atau obat tradisional juga mempunyai efek samping berupa ketergantungan (5) dan dapat menyebabkan kerusakan organ (6) hati dan ginjal (7).

Amlodipine, ibuprofen, prednisolone, tamoxifen (8), insulin (9) merupakan obat-obatan penyebab edemi. Selain dari obat-obatan tersebut adapula obat tradisional yang dapat menyebabkan edemi yakni smilax. Penggunaan ethnomedicinal dari Smilax ovalifolia, yang banyak digunakan oleh berbagai suku dan praktisi obat untuk mengobati berbagai penyakit. Smilax ovalifolia milik keluarga Smilacaceae ini didistribusikan di kawasan hutan di Tengah dan Timur bagian dari Cina, India, Myanmar, Nepal, Thailand dan Vietnam dan daerah sekitarnya (10).

Penggunaan obat tradisional diwaris-kan secara turun temurun dan hingga saat ini banyak tumbuhan 
obat yang terbukti efikasinya secara ilmiah (11). Kurangnya dokumentasi mengenai penggunaan tumbuhan obat oleh komunitas tertentu menyebabkan sulitnya pelestarian obat tradisional tersebut (12). Ditambah lagi dengan adanya modernisasi akibat masuknya kebudayaan dari luar, terutama yang diadopsi oleh generasi muda membuat makin lunturnya pengetahuan lokal pada masyarakat tertentu (13).

Salah satu suku di Indonesia yang masih menjaga budaya dan tradisinya dengan baik adalah suku Tengger di Jawa Timur. Karenanya suku Tengger cenderung lebih cepat mengalami modernisasi teknik manual dan latihan, diterapkan tunggal atau dalam kombinasi untuk mengobati, mendiagnosa, dan mencegah penyakit atau menjaga kesejahteraan (14). Selain di Jawa Timur, ada juga Papua.

Di Papua tumbuh berbagai tumbuhan obat tradisional diantaranya, Tumbuhan wati atau kava (Piper methysticum L; Piperaceae) yang tumbuh baik di dataran rendah Kabupaten Merauke (15). Tanaman ini digunakan untuk mengobati rematik, infeksi saluran pernapasan, TBC, gonore, dan sakit kepala (16). Tali kuning (Tinospora dissitiflora Diels) milik keluarga Menispermaceae, banyak digunakan masyarakat Papua untuk tanaman obat, terutama untuk mengurangi gejala malaria (17). Buah merah (Pandanus conoideus) memiliki efek yang baik pada manfaat kesehatan terkait dengan studi in vivo, sebagai penghambat tumor dan pembunuh sel kanker (18), anti-diabetes (19), anti-inflamasi dan dapat meningkatkan sel kekebalan tubuh (20). Ekstrak biji Matoa (Pometia pinnata) berpotensi sebagai biomedis untuk penyakit diabetes (21). Adapula tumbuhan obat yang ditanam di pekarangan yaitu tumbuhan yang sering digunakan oleh masyarakat ketika sakit seperti cocor bebek (Kalanchoe pinnata) untuk mengobati demam, jarak pagar (Jatropha curcas L.) untuk mengobati sakit sarampa, miayna (Coleus scutellarioides Benth) sebagai obat luka, dan daun gatal (Laportea Sp.) sebagai obat pegal-pegal (22).

Salah satu pengobatan tradisional Papua lainnya yakni penggunaan tumbuhan Smilax $S p$. Tumbuhan Smilax yang merupakan tumbuhan edemik di Papua yang digunakan oleh masyarakat Papua sebagai salah satu tumbuhan obat tradisional belum banyak dilakukan penelitian. Maka perlu dilakukan suatu penelitian tentang penggunaan tumbuhan Smilax sebagai obat tradisional. Penggunaan obat tradisional ternyata juga dapat menimbulkan dampak over dosis atau salah prosedur penggunaan, maka perlu dilakukan penelitian lebih khusus lagi yang mengarah kepada efek lama waktu penggunaan Smilax $S p$ terhadap edemi.

\section{METODOLOGI PENELITIAN}

Pendekatan yang dipakai dalam penelitian ini adalah penelitian eksperimen (23) (24). Tempat pelaksanaan penelitian di Labolatorium Terpadu,
UNIMUDA Sorong yang akan dilaksanakan pada tanggal 24 Mei 2019.

Sampel dalam penelitian ini yakni tanaman Smilax $S p$ yang diperoleh dari Jl. Mawar, Kelurahan Maryat Pantai Distrik Aimas dan Gallus gallus domesticus yang diperoleh dari Jl. Kontener Kabupaten Sorong. Bagian Smilax Sp yang dipakai adalah daun segar yang baru dipetik, Gallus gallus domesticus yang dipakai sebagai sampel adalah Fggd yang berumur 21 hari dalam kondisi sehat, dengan jumlah 12 ekor.

Bahan yang diguankan dalam penelitian ini yaitu daun tumbuhan Smilax Sp, air bersih dan Fggd. Alat yang digunakan yaitu timbangan analitik, nampan, gunting, gunting bedah, pisau, mortal dan pastle, pengaduk, jangka sorong, spatula, ember, kain kasa, perban, cawan petri, lup dan kamera. Teknik dan instrumen pengumpulan data adalah observasi dan dokumentasi.

Teknik analisis data dalam penelitian ini menggunakan metode komparasi yaitu membandingkan keberadaan satu variabel atau lebih pada dua atau lebih sampel, atau pada waktu yang berbeda (25). Data yang diperoleh akan dilakukan perbandingan ukuran dan massa antara Fggd akhir dengan Fggd mula-mula atau Fggd sampel dengan Fggd kontrol, dan akan dideskripsikan secara terperinci.

Gambar-gambar yang diperoleh dari tangkapan kamera akan diolah menggunakan aplikasi Adobe Photoshop 3 untuk memperjelas, mempertajam dan mengkrop fokus pengamatan yang diinginkan.

\section{PEMBAHASAN}

Hasil penelitian tentang keliling superius femur, keliling inferiori femur, tebal sinistram femur musculus, tebal dextro femore, tebal musculus quadriceps, tebal posteriorem femoris, dan massa femur Gallus gallus domesticus diperoleh data sebagai berikut :

Data ukuran keliling superius femur pada kelas kontrol terendah didapat pada sampel 12 dengan ukuran $8,8 \mathrm{~cm}$, dan ukuran keliling superius femur tertinggi terdapat pada sampel 1 dan sampel 4 dengan ukuran $11,5 \mathrm{~cm}$. Ukuran rata-rata keliling superius femur kelas kontrol yakni $10,15 \mathrm{~cm}$. Ukuran keliling superius femur pada kelas eksperimen terendah didapat pada sampel 5 dengan ukuran 9,6 cm, dan ukuran keliling superius femur tertinggi didapat pada sampel 4 dengan ukuran $11,4 \mathrm{~cm}$. Ukuran rata-rata keliling superius femur kelas eksperimen yakni 10,5 $\mathrm{cm}$.

Data ukuran keliling inferiore femur pada kelas kontrol terendah didapat pada sampel 8 dan sampel 12 dengan ukuran $4.5 \mathrm{~cm}$, dan ukuran keliling inferiore femur tertinggi didapat pada sampel 7 dengan ukuran $6 \mathrm{~cm}$. Ukuran rata-rata keliling inferiore femur kelas kontrol yakni $5,25 \mathrm{~cm}$. Ukuran keliling inferiore femur pada kelas eksperimen terendah didapat pada sampel 5 dan sampel 12 dengan ukuran $6,3 \mathrm{~cm}$, dan ukuran keliling inferiore femur tertinggi didapat pada sampel 
9 dengan ukuran $7,5 \mathrm{~cm}$. Ukuran rata-rata keliling inferiore femur kelas eksperimen yakni $6,9 \mathrm{~cm}$.

Data ukuran tebal sinistram femur musculus pada kelas kontrol terendah didapat pada sampel 12 dengan ukuran $0,6 \mathrm{~cm}$, dan ukuran tebal sinistram femur musculus tertinggi didapat pada sampel 3 dengan ukuran $1,2 \mathrm{~cm}$. Ukuran rata-rata tebal sinistram femur musculus kelas kontrol yakni $0,9 \mathrm{~cm}$. Ukuran tebal sinistram femur musculus pada kelas ekperimen terendah didapat pada sampel 5 dan sampel 9 dengan ukuran $0,5 \mathrm{~cm}$, dan ukuran tebal sinistram femur musculus tertinggi didapat pada sampel 8 dengan ukuran $1,1 \mathrm{~cm}$. Ukuran rata-rata tebal sinistram femur musculus kelas eksperimen yakni 0,8 $\mathrm{cm}$.

Data ukuran tebal dextro femore pada kelas kontrol terendah didapat pada sampel 9 dengan ukuran $0,4 \mathrm{~cm}$, dan ukuran tebal dextro femore tertinggi didapat pada sampel 8 dengan ukuran $1,1 \mathrm{~cm}$. Ukuran rata-rata tebal dextro femore kelas kontrol yakni 0,75 $\mathrm{cm}$. Ukuran tebal dextro femore pada kelas eksperimen terendah didapat pada sampel 6 dengan ukuran $1 \mathrm{~cm}$, dan ukuran tebal dextro femore tertinggi didapat pada sampel 8 dengan ukuran $1,6 \mathrm{~cm}$. Ukuran rata-rata tebal dextro femore kelas eksperimen yakni $1,3 \mathrm{~cm}$

Data ukuran tebal musculus quadriceps pada kelas kontrol terendah didapat pada sampel 6, 7,9 dan 12 dengan ukuran $0,7 \mathrm{~cm}$, dan ukuran tebal musculus quadriceps tertinggi didapat pada sampel 8 dengan ukuran $1,1 \mathrm{~cm}$. Ukuran rata-rata tebal musculus quadriceps kelas kontrol yakni $0,85 \mathrm{~cm}$. Ukuran tebal musculus quadriceps pada kelas eksperimen terendah didapat pada sampel 2 dan sampel 6 dengan ukuran 1 $\mathrm{cm}$, dan ukuran tebal musculus quadriceps tertinggi didapat pada sampel 8 dengan ukuran 1,6 cm. Ukuran rata-rata tebal musculus quadriceps kelas eksperimen yakni $1,3 \mathrm{~cm}$.

Data ukuran tebal posteriorem femoris pada kelas kontrol terendah didapat pada sampel 12 dengan ukuran $1 \mathrm{~cm}$, dan ukuran tebal posteriorem femoris tertinggi didapat pada sampel 1 dengan ukuran $1,6 \mathrm{~cm}$. Ukuran rata-rata tebal posteriorem femoris kelas kontrol yakni $1,3 \mathrm{~cm}$. Ukuran tebal posteriorem femoris pada kelas eksperimen terendah didapat pada sampel 12 dengan ukuran $1,1 \mathrm{~cm}$, dan ukuran tebal posteriorem femoris tertinggi didapat pada sampel 7 dengan ukuran $1,9 \mathrm{~cm}$. Ukuran rata-rata tebal posteriorem femoris kelas eksperimen yakni $1,5 \mathrm{~cm}$.

Data ukuran massa femur pada kelas kontrol terendah didapat pada sampel 12 dengan ukuran 31,26 gram, dan ukuran massa femur tertinggi didapat pada sampel 3 dengan ukuran 53,43 gram. Ukuran rata-rata massa femur kelas kontrol yakni 42,345 gram. Ukuran massa femur pada kelas eksperimen terendah didapat pada sampel 9 dengan ukuran 22,08 gram, dan ukuran massa femur tertinggi didapat pada sampel 3 dengan ukuran 52,09 gram. Ukuran rata-rata massa femur kelas ekspeimen yakni 37,085g.
Data pada gambar 3.1 menunjukkan perbandingan selisih antara kelas kontrol dan kelas eksperimen keliling superius femur mengalami -

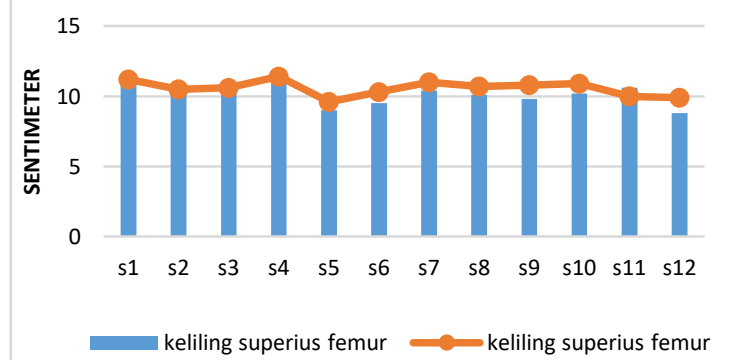

\section{Gambar 3.1 Data hasil perbandingan keliling} superius femur

penurunan selisih yang signifikan terjadi pada jam ke 2 (S1), jam ke 8 (S4), jam ke 22 (S11) dengan masingmasing perbandingan selisih sebesar $(-0,3 \mathrm{~cm}),(-0,1$ $\mathrm{cm})$ dan $(-0,6 \mathrm{~cm})$. Perbandingan selisih antara kelas kontrol dan kelas eksperimen keliling superius femur mengalami kenaikan selisih terjadi pada jam ke 4 (S2), jam ke 6 (S3), jam ke 10 (S5), jam ke 12 (S6) dengan masing-masing perbandingan selisih sebesar $0,2 \mathrm{~cm}$, $0,4 \mathrm{~cm}, 0,6 \mathrm{~cm}$, dan $0,8 \mathrm{~cm}$.

Perbandingan selisih antara kelas kontrol dan kelas eksperimen keliling superius femur kembali mengalami penurunan pada jam ke 14 (S7) dan jam ke 16 (S8) dengan besar perbandingan selisih yang sama yakni 0,6 cm, namun pada jam ke 18 (S9) perbandingan selisih keliling superius femur kembali mengalami kenaikan antara kelas kontrol dan kelas eksperimen dengan perbandingan selisih sebesar $1 \mathrm{~cm}$. Perbandingan selisih antara kelas kontrol dan kelas eksperimen keliling superius femur kembali mengalami penurunan pada jam ke 20 (S10) dengan perbandingan selisih sebesar $0,7 \mathrm{~cm}$ dan perbandingan selisih keliling superius femur mengalami kenaikan kembali pada jam ke 24 (S12) dengan perbandingan selisih sebesar $1,1 \mathrm{~cm}$.

Perbandingan selisih terkecil antara kelas kontrol dan kelas eksperimen keliling superius femur di dapat pada jam ke 8 (S4) dengan besar selisih -0,1 $\mathrm{cm}$ dan perbandingan selisih terbesar antara kelas kontrol dan kelas eksperimen keliling superius femur di dapat pada jam ke 24 (S12) dengan besar selisih 1,1 $\mathrm{cm}$.

Data pada gambar 3.2 menunjukkan perbandingan selisih antara kelas kontrol dan kelas eksperimen keliling inferiore femur jam ke 2 (S1), jam ke 6 (S3), jam ke 12 (S6), jam ke 20 (S10) di dapat perbandingan selisih dengan besar yang sama yakni 2,3 cm. Perbandingan selisih antara kelas kontrol dan kelas eksperimen keliling inferiore femur mengalami penurunan pada jam ke 4 (S2), jam ke 8 (S4), jam ke 10 (S5), jam ke 14 (S7) dengan masing-masing perbandingan selisih sebesar $1,9 \mathrm{~cm}, 1,5 \mathrm{~cm}, 1,1 \mathrm{~cm}$ dan $1 \mathrm{~cm}$, namun pada jam ke 4 (S2), jam ke 8 (S4), jam ke 10 (S5), jam ke 14 (S7) dengan masing-masing perbandingan selisih sebesar $1,9 \mathrm{~cm}, 1,5 \mathrm{~cm}, 1,1 \mathrm{~cm}$ dan $1 \mathrm{~cm}$, namun pada jam ke 16 (S8) dan jam ke 18 
(S9) perbandingan selisih kembali mengalami kenaikan antara kelas kontrol dan kelas eksperimen dengan masing-masing perbandingan selisih sebesar 2

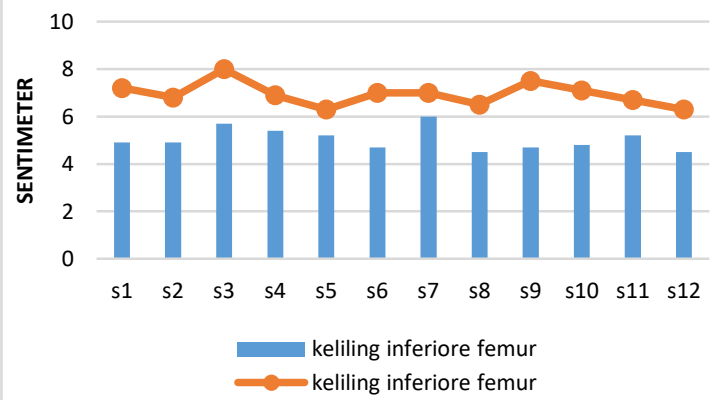

Gambar 3.2 Data perbandingan keliling inferiore femur

$\mathrm{cm}$ dan $2,8 \mathrm{~cm}$. Perbandingan selisih antara kelas kontrol dan kelas eksperimen keliling inferiore femur kembali mengalami penurunan pada jam ke 22 (S11) di dapat perbandingan selisih sebesar $1,5 \mathrm{~cm}$, dan perbandingan selisih antara kelas kontrol dan kelas eksperimen keliling inferiore femur kembali mengalami kenaikan pada jam 24 (S12) dengan besar perbandingan selisih $1,8 \mathrm{~cm}$.

Perbandingan selisih terkecil antara kelas kontrol dan kelas eksperimen keliling inferiore femur di dapat pada jam ke 14 (S7) dengan besar selisih 1 $\mathrm{cm}$ dan perbandingan selisih terbesar antara kelas kontrol dan kelas eksperimen keliling inferiore femur di dapat pada jam ke 18 (S9) dengan besar selisih 2,8 $\mathrm{cm}$.

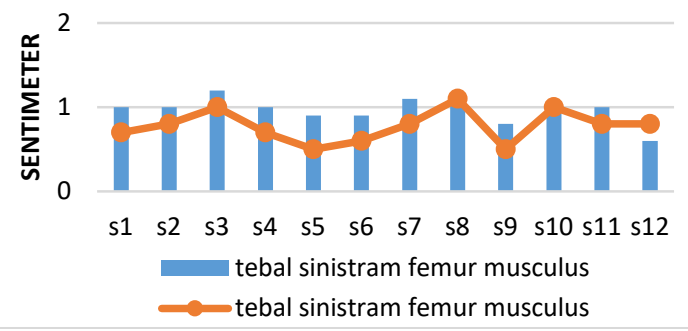

Gambar 3.3 Data perbandingan tebal sinistram femur musculus

Data pada gambar 3.3 menunjukkan tidak adanya perbandingan selisih tebal sinistram femur musculus antara kelas kontrol dan kelas eksperimen di dapat pada jam ke 16 (S8), jam ke 20 (S10). Perbandingan selisih antara kelas kontrol dan kelas eksperimen tebal sinistram femur musculus mengalami penurunan selisih yang signifikan terjadi pada jam ke 2 (S1), jam ke 4 (S2), jam ke 6 (S3), jam ke 8 (S4), jam ke 10 (S5), jam ke 12 (S6), jam ke 14 (S7), jam ke 18 (S9) dan jam ke 22 (S11) dengan besar masing-masing perbandingan selisih yakni $(-0,3$ $\mathrm{cm}),(-0,2 \mathrm{~cm}),(-0,2 \mathrm{~cm}),(-0,3 \mathrm{~cm}),(-0,4 \mathrm{~cm}),(-0,3$ $\mathrm{cm}),(-0,3 \mathrm{~cm}),(-0,3 \mathrm{~cm})$ dan $(-0,2 \mathrm{~cm})$. Perbandingan selisih antara kelas kontrol dan kelas eksperimen tebal sinistram femur musculus mengalami kenaikan pada jam ke 24 (S12) dengan perbandingan selisih sebesar $0,2 \mathrm{~cm}$.
Perbandingan selisih terkecil antara kelas kontrol dan kelas eksperimen tebal sinistram femur musculus di dapat pada jam ke 10 (S5) dengan besar selisih $(-0,4 \mathrm{~cm})$ dan perbandingan selisih terbesar antara kelas kontrol dan kelas eksperimen tebal sinistram femur musculus di dapat pada jam ke 24 (S12) dengan besar selisih $0,2 \mathrm{~cm}$.

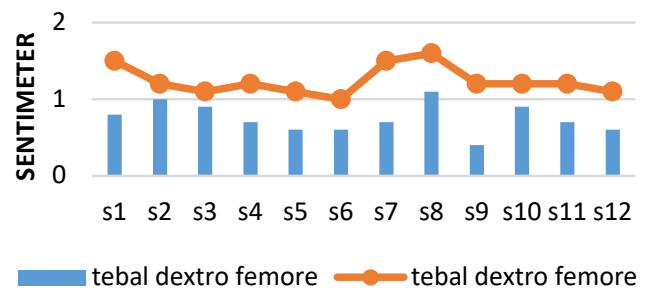

Gambar 3.4 Data perbandingan tebal dextro femore

Data pada gambar 3.4 menunjukkan perbandingan selisih antara kelas kontrol dan kelas eksperimen tebal dextro femore jam ke 14 (S7) dan jam ke 18 (S9) di dapat perbandingan selisih dengan besar yang sama yakni $0,8 \mathrm{~cm}$. Perbandingan selisih antara kelas kontrol dan kelas eksperimen tebal dextro femore jam ke 2 (S1) di dapat perbandingan selisih sebesar $0,7 \mathrm{~cm}$. Perbandingan selisih antara kelas kontrol dan kelas eksperimen tebal dextro femore mengalami penurunan selisih pada jam ke 4 (S2) dan jam ke 6 (S3) dengan besar perbandingan selisih yang sama yakni $0,2 \mathrm{~cm}$.

Perbandingan selisih antara kelas kontrol dan kelas eksperimen tebal dextro femore jam ke 8 (S4), jam ke 10 (S5), jam ke 16 (S8), jam ke 22 (S11), jam ke 24 (S12) mengalami besar perbandingan selisih yang sama yakni $0,5 \mathrm{~cm}$. Perbandingan selisih antara kelas kontrol dan kelas eksperimen tebal dextro femore mengalami penurunan pada jam ke 12 (S6) dan jam ke 20 (S10) dengan besar masing-masing perbandingan selisih yakni $0,4 \mathrm{~cm}$ dan $0,3 \mathrm{~cm}$.

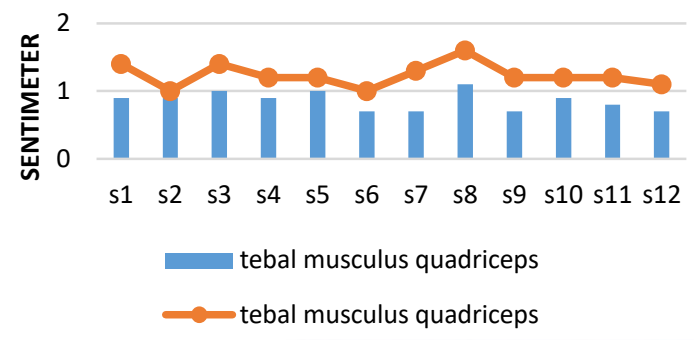

Gambar 3.1 Data perbandingan tebal musculus quadriceps

Data pada gambar 3.5 berikut menunjukkan perbandingan selisih antara kelas kontrol dan kelas eksperimen tebal musculus quadriceps jam ke 2 (S1), jam ke 16 (S8), jam ke 18 (S9) di dapat perbandingan selisih dengan besar yang sama yakni $0,5 \mathrm{~cm}$. Perbandingan selisih antara kelas kontrol dan kelas eksperimen tebal musculus quadriceps mengalami penurunan selisih pada jam ke 4 (S2) dengan perbandingan selisih sebesar $0,1 \mathrm{~cm}$, namun pada jam ke 6 (S3) perbandingan kembali mengalami 
peningkatan antara kelas kontrol dan kelas eksperimen di dapat perbandingan selisih sebesar $0,4 \mathrm{~cm}$.

Perbandingan selisih antara kelas kontrol dan kelas eksperimen tebal musculus quadriceps jam ke 22 (S11) dan jam ke 24 (S12) di dapat perbandingan selisih dengan besar yang sama yakni $0,4 \mathrm{~cm}$, namun pada jam ke 8 (S4), jam ke 12 (S6) dan jam ke 20 (S10) perbandingan selisih antara kelas kontrol dan kelas eksperimen tebal musculus quadriceps mengalami penurunan selisih dengan masing-masing besar perbandingan selisih yang sama yakni $0,3 \mathrm{~cm}$ dan pada jam ke 10 (S5) perbandingan selisih antara kelas kontrol dan kelas eksperimen tebal musculus quadriceps di dapat perbandingan selisih yakni 0.2 $\mathrm{cm}$. Perbandingan selisih antara kelas kontrol dan kelas eksperimen tebal musculus quadriceps pada jam ke 14 (S7) kembali mengalami peningkatan dengan perbandingan selisih yakni $0,6 \mathrm{~cm}$.

Perbandingan selisih terkecil antara kelas kontrol dan kelas eksperimen tebal musculus quadriceps di dapat pada jam ke 4 (S2) dengan besar selisih $0,1 \mathrm{~cm}$ dan perbandingan selisih terbesar antara kelas kontrol dan kelas eksperimen tebal musculus quadriceps di dapat pada jam ke 14 (S7) dengan besar selisih $0,6 \mathrm{~cm}$.

Data pada gambar 3.6 menunjukkan perbandingan selisih antara kelas kontrol dan kelas eksperimen tebal posteriorem femoris jam ke 2 (S1), jam ke 4 (S2), jam ke 6 (S3), jam ke 8 (S4), jam ke 10 (S5), dan jam ke 20 (S10) di dapat perbandingan selisih dengan besar yang sama yakni $0,2 \mathrm{~cm}$.

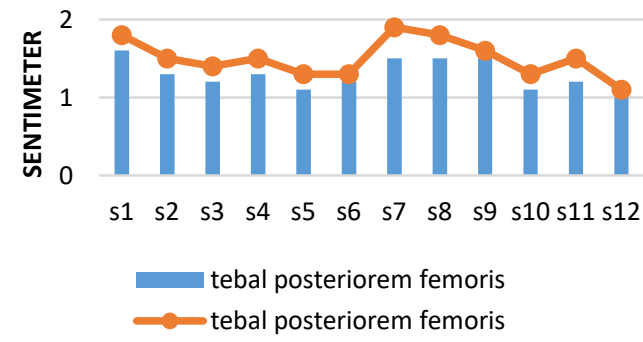

\section{Gambar 3.6 Data perbandingan tebal posteriorem femoris}

Perbandingan selisih antara kelas kontrol dan kelas eksperimen tebal posteriorem femoris mengalami penurunan pada jam ke 12 (S6), jam ke 18 (S9), dan jam ke 24 (S12) dengan besar perbandingan selisih yang sama yakni $0,1 \mathrm{~cm}$.

Perbandingan selisih antara kelas kontrol dan kelas eksperimen tebal posteriorem femoris kembali mengalami peningkatan pada jam ke 14 (S7) di dapat perbandingan selisih sebesar $0,4 \mathrm{~cm}$, namun pada jam ke 16 (S8) dan jam ke 22 (S11) perbandingan selisih mengalami penurunan kembali antara kelas kontrol dan kelas eksperimen di dapat perbandingan selisih dengan besar yang sama yakni $0,3 \mathrm{~cm}$.

Perbandingan selisih terkecil antara kelas -

kontrol dan kelas eksperimen tebal posteriorem femoris di dapat pada jam ke 12 (S6), jam ke 18 (S9) dan jam ke 24 (S12) dengan besar selisih 0,1 cm dan perbandingan selisih terbesar antara kelas kontrol dan kelas eksperimen tebal posteriorem femoris di dapat pada jam ke 14 (S7) dengan besar selisih $0,4 \mathrm{~cm}$.

Data pada gambar 3.7 menunjukkan perbandingan selisih antara kelas kontrol dan kelas eksperimen massa femur mengalami penurunan selisih yang signifikan terjadi pada jam ke 18 (S9), jam ke 10 (S5), jam ke 2 (S1), jam ke 14 (S7), jam ke 16 (S8), jam ke 6 (S3), jam ke 20 -

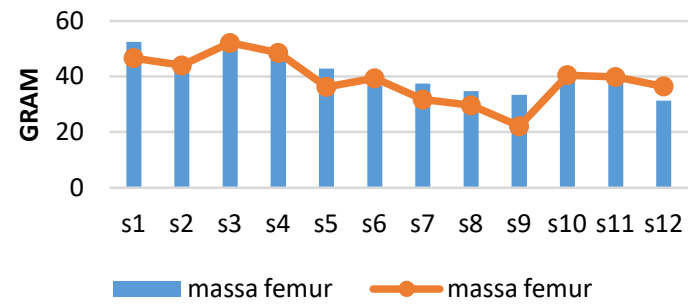

Gambar 3.7 Data perbandingan massa femur (S10) dan jam 8 (S4) dengan masing-masing perbandingan selisih sebesar (-11,38 gram), (-6,54 gram), (-5,81 gram), (-5,71 gram), (-5,2 gram), (-1,34 gram $),(-1,11$ gram $)$ dan $(-0,46$ gram $)$.

Perbandingan selisih antara kelas kontrol dan kelas eksperimen massa femur mengalami peningkatan selisih terjadi pada jam ke 4 (S2) dan jam ke 12 (S6) dengan masing-masing perbandingan selisih sebesar 1,66 gram dan 2,7 gram namun pada jam ke 22 (S11) perbandingan selisih massa femur mengalami penurunan antara kelas kontrol dan kelas eksperimen di dapat perbandingan selisih sebesar 0,99 gram dan pada jam ke 24 (S12) perbandingan selisih massa femur kembali mengalami kenaikan dengan perbandingan selisih sebesar 5,2 gram.

Perbandingan selisih terkecil antara kelas kontrol dan kelas eksperimen massa femur di dapat pada jam ke 20 (S10) dengan besar selisih (-1,11 gram) dan perbandingan selisih terbesar antara kelas kontrol dan kelas eksperimen massa femur di dapat pada jam ke 24 (S12) dengan besar selisih 5.2 gram.

Hasil dari penelitian diperoleh fakta superior femur pada umumnya mengalami edemi. Hal ini diakibatkan dari adanya komponen tertentu pada daun Smilax $S p$ yang menjadi penyebab terjadinya edemi. Edemi yang terjadi pada superior femur sesuai dengan fakta dari hasil penelitian (26) dimana edemi disebabkan karena adanya komponen zat tertentu.

Beberapa sampel menunjukkan fakta tidak terjadinya yakni S1, S4 dan S11. S1 perlakuan 2 jam, S4 perlakuan 8 jam dan S11 perlakuan 22 jam tidak terjadinya edemi pada sampel-sampel ini dikarenakan komposisi zat dalam satu dosis pada interval waktu yang ditentukan (27). Selain itu, waktu maksimal pencapaian obat yang bervariasi juga berpengaruh terhadap edemi. Beberapa sampel menunjukkan fakta tidak terjadinya edemi (28).

Pembungkusan dengan edemi tertinggi terdapat pada sampel 12 perlakuan 24 jam. Ini menunjukkan bahwa proses edemi superior femur maximum terjadi pada waktu 24 jam. Adanya batasan waktu tersebut 
pada proses edemi akibat adanya tingkat batasan massa aktif suatu zat, sesuai dengan pendapat dari (29) yang menyatakan durasi kerja suatu zat adalah lamanya waktu efektif zat tersebut.

Hasil dari penelitian diperoleh fakta inferiore femur pada umumnya mengalami edemi. Hal ini diakibatkan dari adanya komponen tertentu pada daun Smilax yang digunakan sebagai perlakuan. Edemi yang terjadi pada inferiore femur sesuai dengan fakta dari hasil penelitian (30) dimana edemi dapat terjadi akibat adanya efek samping dari zat tertentu, maupun karena reaksi alergi.

Pembungkusan dengan edemi tertinggi terdapat pada sampel 9 perlakuan 18 jam. Hal ini menunjukkan bahwa proses edemi inferiore femur maximum terjadi pada waktu 18 jam. Adanya batasan waktu tersebut pada proses edemi sesuai dengan pendapat dari (31) yang menyatakan penggunaan dosis dalam waktu lama dapat menyebabkan penimbunan zat signifikan yang dapat muncul seiring waktu.

Hasil dari penelitian diperoleh fakta sinistram femur musculus pada umumnya mengalami edemi. Hal ini diakibatkan dari adanya komponen tertentu pada daun Smilax $S p$ yang digunakan sebagai perlakuan. Edemi yang terjadi pada sinistram femur musculus sesuai dengan fakta dari hasil penelitian (32) dimana edemi merupakan pembengkakan abnormal yang disebabkan oleh akumulasi cairan pada jaringan yang merupakan respons tubuh terhadap suatu zat.

Beberapa sampel menunjukkan fakta tidak terjadinya edemi yakni S1, S2, S3, S4, S5, S6, S7, S8, S9, S10 dan S11. S1 perlakuan 2 jam, S2 perlakuan 4 jam, S3 perlakuan 6 jam, S4 perlakuan 8 jam, S5 perlakuan 10 jam, S6 perlakuan 12 jam, S7 perlakuan 14 jam, S8 perlakuan 16 jam, S9 perlakuan 18 jam, S10 perlakuan 20 jam dan S11 perlakuan 22 jam, tidak terjadinya edemi pada sampel-sampel ini dikarenakan efek samping atau toksisitas zat mengakibatkan menurunnya kadar zat dalam plasma yang menyebabkan hasil menjadi tidak optimal (33).

Pembungkusan dengan edemi ter-tinggi terdapat pada sampel 12 perlakuan 24 jam. Ini menunjukkan bahwa proses edemi sinistram femur musculus maximum terjadi pada waktu 24 jam. Adanya batasan waktu tersebut pada proses edemi sesuai dengan fakta hasil penelitian (34) yang menyatakan dosis zat mempengaruhi lama waktu efektif zat tersebut.

Hasil dari penelitian diperoleh fakta dextro femore pada umumnya mengalami edemi. Hal ini diakibatkan dari adanya komponen tertentu pada daun Smilax $S p$ yang digunakan sebagai perlakuan. Edemi yang terjadi pada dextro femore sesuai dengan fakta dari (35) yang menyatakan edemi dapat terjadi akibat adanya reaksi alergi dimana ketika sistem kekebalan mendeteksi adanya zat asing.

Pembungkusan dengan edemi tertinggi terdapat pada sampel 7 perlakuan 14 jam dan S9 perlakuan 18 jam. Ini menunjukkan bahwa proses edemi dextro femore maximum terjadi pada waktu 14 jam dan 18 jam. Adanya batasan waktu tersebut pada proses edemi sesuai dengan fakta hasil penelitian dari (36) dimana suatu zat tidak selalu bekerja dengan segera, perlu waktu untuk menemukan dan menghasilkan hasil yang optimal.

Hasil dari penelitian diperoleh fakta musculus quadriceps pada umumnya mengalami edemi. Hal ini diakibatkan dari adanya komponen tertentu pada daun Smilax $S p$ yang digunakan sebagai perlakuan. Edemi yang terjadi pada musculus quadriceps sesuai dengan fakta dari hasil penelitian (37) dimana edemi merupakan pembengkakan jaringan lunak akibat peningkatan cairan interstitial yang sebagian besar adalah air, tetapi juga protein yang dapat menumpuk karena adanya infeksi.

Pembungkusan dengan edemi tertinggi terdapat pada sampel 7 perlakuan 14 jam. Ini menunjukkan bahwa proses edemi musculus quadriceps maximum terjadi pada waktu 14 jam. Adanya batasan waktu tersebut pada proses edemi sesuai dengan fakta hasil penelitian dari (38) yang menyatakan respon suatu zat terjadi dalam tiga fase diantaranya; fase akut (vasodilatasi lokal dan peningkatan permeabilitas kapiler), reaksi lambat atau tahap subakut (infiltrasi sel leukosit dan fagosit) dan fase proliferatif kronik (terjadinya degenerasi dan fibrosis).

Hasil dari penelitian diperoleh fakta posteriorem femoris pada umumnya mengalami edemi. Hal ini diakibatkan dari adanya komponen tertentu pada daun Smilax $S p$ yang digunakan sebagai perlakuan. Edemi yang terjadi pada posteriorem femoris sesuai dengan fakta dari hasil penelitian (39) dimana edemi terjadi akibat adanya reaksi alergi terhadap suatu zat tertentu.

Pembungkusan dengan edemi tertinggi terdapat pada sampel 7 perlakuan 14 jam. Ini menunjukkan bahwa proses edemi posteriorem femoris maximum terjadi pada waktu 14 jam. Adanya batasan waktu tersebut pada proses edemi sesuai dengan fakta hasil penelitian dari (28) Schachter S. C, et al, (2013).

Hasil dari penelitian diperoleh fakta femur pada umumnya mengalami edemi. Hal ini diakibatkan dari adanya komponen tertentu pada daun Smilax $S p$ yang digunakan sebagai perlakuan. Edemi yang terjadi menyebabkan perubahan pada massa femur sesuai dengan fakta dari hasil penelitian (40) dimana edemi dapat terjadi sebagai akibat dari bekuan darah di vena dalam pada femur yang dihasilkan dari reaksi alergi (41).

Beberapa sampel menunjukkan fakta tidak terjadinya edemi yakni pada S1, S3, S4, S5, S7, S8, S9 dan S10. S1 perlakuan 2 jam, S3 perlakuan 6 jam, S4 perlakuan 8 jam, S5 perlakuan 10 jam, S7 perlakuan 14 jam, S8 perlakuan 16 jam, S9 perlakuan 18 jam dan S10 perlakuan 20 jam tidak terjadinya edemi pada sampel-sampel ini dikarenakan tingkat efektivitas suatu zat dapat berkurang dalam pemakaian jangka lama zat tersebut (42).

Pembungkusan dengan edemi tertinggi terdapat 
pada sampel 12 perlakuan 24 jam. Ini menunjukkan bahwa proses edemi mempengaruhi massa femur dengan massa femur maximum terjadi pada waktu 24 jam. Adanya batasan waktu tersebut pada proses edemi sesuai dengan fakta hasil penelitian dari (33) Bertolino J.G, et al, (2000).

Secara keseluruhan, terbukti lama waktu pembungkusan berpengaruh terhadap edemi maximum pada Femur Gallus gallus domesticus.

\section{KESIMPULAN}

Berdasarkan hasil penelitian maka dapat disimpulkan bahwa lama waktu penggunaan daun Smilax $S p$ berdampak terhadap proses edemi pada superius femur, inferior femur, sinistram femur musculus, dextro femur, musculus quadriceps, posteriorem femoris dan merubah massa femur. Beberapa sampel menunjukkan fakta tidak terjadinya edemi dikarenakan waktu maksimal pencapaian suatu zat bervariasi. Proses edemi yang maksimum terjadi pada jam ke 14, dengan persentasi edemi sebesar 114 $\%$.

\section{DAFTAR PUSTAKA}

1. A Review on Edema . Aslesha, E. 2016, Research and Reviews: Journal of Pharmaceutical Analysis, pp. 63-70.

2. Navigasi Laser Photocoagulation dari Edema Kronis Diabetic Kronis. Hejsek L, et al. 2015, J Clin Exp Ophthalmol, p. 6: 414.

3. Pemantauan Pola Tekanan Intraokular 24-Jam Secara Terus-Menerus di Normal Yang Diproses Medis. Gordon SK, et al. 2014, Bedah Curr Res, p. 4: 193.

4. Pola pemberian antibiotika pengobatan demam tifoid Anak di rumah sakit fatmawati jakarta tahun 2001-2002. Musnelina L. et al. 2004, Makara Kesehatan, p. 8.

5. Farmakologi Dasar dan Klinik (edisi 8). Katzung, B. C. 2002, Salemba Medika.

6. Herbal medicine in the United States: review of efficacy, safety, and regulation. Bent, S. 2008, Journal of General Internal Medicine, pp. 854-859.

7. Goodman \& Gilman's The Pharmacological Basis of Therapeutics (eleventh edition). Brunton, L. et al. 2010, New York: McGraw-Hill.

8. Keeley V. and Piller N. www.lymphedivas.com. [Online] 2017. http://canadalymph.ca/wpcontent/uploads/2015/04/Edema-causingmedications.pdf.

9. Insulin-induced Oedema in a Patient with Diabetes Mellitus Complicated by Ketoacidosis. Alphonsus N. et al. 2014, Acta Medica Indonesiana - The Indonesian Journal of Internal Medicine, p. 325.

10. A Review on Ethnobotanical uses of Smilax ovalifolia. Shah, Rajesh Kumar. 2015, International Journal of Herbal Medicine, p. 16.

11. Penebar Swadaya. Syukur,et al. 2002, Budidaya tanaman obat komersial, p. Jakarta.
12. Penggalian IPTEK etnomedisin . Rosita et al. 2007, Penggalian IPTEK etnomedisin di Pangrango, pp. 13-28.

13. the law and politics of protection. Bodeker et al. 2000, Indigenous medical knowledge.

14. Herbal mixtures in traditional medicine in Northern Peru. Bussmann et al. 2010, Journal of Ethnobiology and Ethnomedicine, pp. 1-11.

15. Upaya pelestarian wati (Piper methysticum) tanaman obat, wowirian (Pandorea pandorana) dan jilat (Villebrunea trinervia) dari Papua. Nova. 2009, Warta Penelitian Pengembangan, pp. 27-30.

16. Pemanfaatan dan domestikasi tanaman obat wati (kava, Piper domesticum L.) secara tradisional oleh suku Marind di Papua [Indonesia]. Tanjung et al. 2014, Prosiding dari Seminar Nasional Biologis Indonesia, pp. 104-124.

17. Suebu, J. Bachelor Thesis in Forest Science. Indonesia : State Univ. of Papua, Indonesia, 2003.

18. Keanekaragaman Hayati Indonesia, dari Mikroba hingga Tanaman Herbal sebagai Makanan Potensial Fungsional. Surono et al. 2008, Jurnal Fakultas Pertanian Universitas Shinshu 44, pp. 2327.

19. Pengaruh Pandanus conoideus Lam. minyak pada sel $\beta$ pankreas danefek hipoglikemik glibenklamid dari diabetes Wistar tikus. Winarto et al. 2009, Berkala Ilmu Kedokteran 41 (1), pp. 11-19.

20. Inhibition of $N F-\kappa B$ pathway as the therapeutic potential of red fruit (Pandanus conoideus L.) in the treatment of inflammatory bowel disease. Khiong et al. 2009, Journal of Medical Maranatha 9(1), pp. 69-75.

21. Evaluation of antidiabetes activity of matoa seed extract (Pometia pinnata) using enzym $\alpha$ glucosidase. Sukiman M. et al. 2018, The Pharma Innovation Journal 2018; 7(5), pp. 10-12.

22. Etnobotani Tumbuhan Pangan dan Obat Masyarakat Suku ARFAK Di Kampung Warmare, Kabupaten Manokwari. Bawoleh N. A. et al. 2017, UNIVERSITAS ATMA JAYA YOGYAKARTA FAKULTAS TEKNOBIOLOGI PROGRAM STUDI BIOLOGI YOGYAKARTA, p. 11.

23. Asmadi, A. Pendekatan Kuantitatif Kualitatif dalam Penelitian Psikologi. Yogyakarta: Pustaka Pelajar, 2004.

24. Psikologi Eksperimen. Latipun. 2004, pp. 70-71.

25. Nazir, Moh. Metode Penelitian. Metode Penelitian. Jakarta : Ghalia Indonesia, 2005.

26. WebMD. [Online] 2019. https://webmd.com/heartdisease/heart-failure/edema-overview\#1.

27. Purse M. https://www.verywellmind.com. [Online] September https://www.verywellmind.com/medication-halflife-380031.

28. Schachter S. C, et al. https://www.epilepsy.com. epilepsy foundation. [Online] Juli 2013. https://www.epilepsy.com/learn/treating-seizures- 
and-epilepsy/seizure-and-epilepsy-medicines/howlong-until-medicine-works.

29. Duration of drug action. Carruthers SG. 1980 Am. Fam. Physician.

30. Trayes K. P. et al. American Family Physician. www.aafp.org/afp. [Online] July 2013. www.aafp.org/afp/2013/0715/p102.pdf.

31. Fox C, et al. Clinical Aspects of Pain Medicine and Interventional Pain Management: A Comprehensive Review. Paducah : 2011, 2011.

32. Treatment of edema. O'Brien J.G, et al. 2005, American Family Physician.

33. Clinical pharmacology: clinically significant drug interaction. Bertolino J.G, et al. 2000, Am Fam Physicia, p. 54.

34. Therapeutic Drug Monitoring (TDM) pada Penggunaan Aspirin. Miladiyah I. 2012, p. 212.

35. medlineplus.gov. [Online] 1997. https://medlineplus.gov/ency/article/000846.htm.

36. Hughes L. https://www.huffpost.com. [Online] May 20 , 2019. https://www.huffpost.com/entry/anti-anxietymedication_1_5ce2b712e4b00e035b94c6b9.

37. Thompson A. D., et al. https://www.merckmanuals.com. [Online] Juni 2018.

https://www.merckmanuals.com/professional/cardi ovascular-disorders/symptoms-of-cardiovasculardisorders/edema.

38. Wilmana, F.P.,. Farmakologi dan Terapi. Jakarta : s.n., 2007.

39. "Risperidone and allergic reactions". Terao T. et al. 1998, Journal of Clinical Psychiatry, pp. 82-83.

40. Sterns R. H. Patient education: Edema (swelling) (Beyond the Basics). UpToDate. [Online] Desember 2017. https://www.uptodate.com/contents/edemaswelling-beyond-the-basics.

41. Peripheral Edema. Cho, S. and Atwood, J. E. 2002, The American Journal Of Medicine, p. 580.

42. Soegondo S. Penatalaksanaan Diabetes Melitus Terpadu. Jakarta : s.n., 2013. 